\title{
Antimony uptake by Zea mays (L.) and Helianthus annuus (L.) from nutrient solution
}

\section{Conference Paper}

\section{Author(s):}

Tschan, Martin; Robinson, Brett; Schulin, R.

Publication date:

2008

Permanent link:

https://doi.org/10.3929/ethz-b-000011071

Rights / license:

In Copyright - Non-Commercial Use Permitted

Originally published in:

Environmental Geochemistry and Health 30(2), https://doi.org/10.1007/s10653-008-9142-4 


\title{
Antimony uptake by Zea mays (L.) and Helianthus annuus (L.) from nutrient solution
}

\author{
Martin Tschan · Brett Robinson · Rainer Schulin
}

Received: 13 October 2006/Accepted: 2 June 2007/Published online: 6 February 2008

(C) Springer Science+Business Media B.V. 2008

\begin{abstract}
We investigated the extent of $\mathrm{Sb}$ uptake by maize (Zea mays) and sunflower (Helianthus annuus) from nutrient solutions containing concentrations from 3 to $24 \mathrm{mg} / \mathrm{L}$ of potassium antimonate, with the aim of determining the potential of $\mathrm{Sb}$ to enter the food chain. The maximum shoot $\mathrm{Sb}$ concentrations in $Z$. mays and $H$. annuus were $41 \mathrm{mg} / \mathrm{kg}$ and $77 \mathrm{mg} / \mathrm{kg}$ dry weight, respectively. There was no significant difference in Sb uptake between species. The average bioaccumulation coefficients (the plant/solution concentration quotients) were 1.02 and 1.93 for Z. mays and H. annuиs, respectively. Phosphate addition did not affect plant growth or $\mathrm{Sb}$ uptake. Antimony uptake by both $Z$. mays and $H$. annuus is unlikely to pose a health risk to animals and humans.
\end{abstract}

Keywords Antimony - Crop plants - Food chain HG-AFS · Plant uptake · Phosphorous

\section{Introduction}

Antimony ( $\mathrm{Sb})$ is a rare element in the Earth's crust, occurring at $0.2-0.3 \mathrm{mg} / \mathrm{kg}$ (Rish 2004). Common

M. Tschan $(\square) \cdot$ B. Robinson · R. Schulin Institute of Terrestrial Ecosystems, Soil Protection, Swiss Federal Institute of Technology, Universitaetstrasse 16, 8092 Zurich, Switzerland e-mail: martin.tschan@env.ethz.ch minerals are sulfides (in particular stibnite $\mathrm{Sb}_{2} \mathrm{~S}_{3}$ ) and oxides (valentinite $\mathrm{Sb}_{2} \mathrm{O}_{3}$ and cervantite $\mathrm{Sb}_{2} \mathrm{O}_{4}$ ). However, it has become widespread in the environment because of its industrial uses in fire retardants, semiconductors, and as an agent for metal hardening (Filella et al. 2002). Antimony consumption has increased with global economic growth, resulting in elevated $\mathrm{Sb}$ concentrations in soils and natural waters, where it may affect plants, animals, and humans.

In Switzerland, high levels of $\mathrm{Sb}$ occur in soils associated with the approximately 2,000 shooting ranges scattered throughout the country (Gresch and Wettstein 2002). On average, new bullets and pellets consist of over $90 \% \mathrm{~Pb}, 1-7 \% \mathrm{Sb},<2 \%$ arsenic (As), and $<0.5 \%$ nickel (Ni) (Rooney et al. 1999). Johnson et al. (2005) reported that $\mathrm{Sb}$ was the most soluble and mobile of all the trace element contaminants in Swiss shooting ranges. Wersin et al. (2002) reported elevated $\mathrm{Sb}$ concentrations in receiving waters near a Swiss shooting range.

Antimony is a nonessential element for both plants and animals. Antimony is toxic to humans at chronic uptake rates exceeding $100 \mathrm{mg} / \mathrm{d}$ (Bowen 1979); rats are susceptible to an intake of $11-75 \mathrm{mg} / \mathrm{d}$. Due to its toxicity and potential carcinogenic nature, there are regulations regarding human exposure to $\mathrm{Sb}$ in the workplace (Rish 2004). The European Union (EU) limit for Sb in drinking water is $5 \mu \mathrm{g} / \mathrm{L}$ (Filella et al. 2002). The European Commission has set a threshold of $0.04 \mathrm{mg} \mathrm{Sb} / \mathrm{kg}$ for plastic materials and articles 
intended to come into contact with food (EU 2005). To date, there are no Swiss limits for antimony in soil and food. The Dutch intervention values for $\mathrm{Sb}$ in soil and groundwater are $15 \mathrm{mg} / \mathrm{kg}$ and $20 \mu \mathrm{g} / \mathrm{L}$, respectively (Swartjes 1999).

The biogeochemical behavior of $\mathrm{Sb}$ is in similar to the other group VI elements arsenic (As) and phosphorous $(\mathrm{P})$. It is a metalloid that exists in four oxidation states: - III, $0,+$ III, and + V. In the environment, Sb usually occurs as $\mathrm{Sb}(\mathrm{III})$ (antimonite) and $\mathrm{Sb}(\mathrm{V})$ (antimonate) in reducing and oxidizing conditions, respectively. In soils, $\mathrm{Sb}(\mathrm{III})$ is oxidized within hours to $\mathrm{Sb}(\mathrm{V})$ (Krachler et al. 2001).

Compared to other trace elements, $\mathrm{Sb}$ is relatively mobile in soils, increasing the likelihood of its entry into the food chain via plant uptake (Gresch and Wettstein 2002). Ainsworth et al. (1990a) measured $\mathrm{Sb}$ concentrations in the leaves of several grasses growing adjacent to an $\mathrm{Sb}$ smelter in Northeast England, where soil $\mathrm{Sb}$ concentrations reached $400 \mathrm{mg} / \mathrm{kg}$. They found leaf $\mathrm{Sb}$ concentrations of over $300 \mathrm{mg} / \mathrm{kg}$ in some samples. Grasses grown near the smelter in pots that contained noncontaminated soil had similar Sb concentrations to plants growing in contaminated soil. This indicated that leaf $\mathrm{Sb}$ burden came from surface deposition, rather than plant uptake. Nevertheless, invertebrates and mammals that fed on these plants had elevated Sb concentrations in various tissues (Ainsworth et al. 1990b).

Baroni et al. (2000) reported Sb levels of over $1,000 \mathrm{mg} / \mathrm{kg}$ in the basal leaves of Achillea ageratum growing in a mine soil containing $9,000 \mathrm{mg} / \mathrm{kg} \mathrm{Sb}$. Other species growing in the same soil also had foliar $\mathrm{Sb}$ concentrations greater than $100 \mathrm{mg} / \mathrm{kg}$. Conversely, Pratas et al. (2005) reported maximum stem concentrations of less than $5 \mathrm{mg} / \mathrm{kg} \mathrm{Sb}$ for species growing in a Portuguese mine soil with an average soil concentration of $663 \mathrm{mg} / \mathrm{kg}$. There is a lack of information on possible mechanisms of $\mathrm{Sb}$ toxicity in plants.

The aforementioned studies indicate that there is large interspecific variability in plant uptake of $\mathrm{Sb}$ and that surface deposition can account for a large proportion of total $\mathrm{Sb}$ content of plant stems and foliage collected in the field.

Given that $\mathrm{Sb}$ has similar chemical properties to As and $\mathrm{P}$, plants may take it up by the same mechanism. It has been shown that the addition of $\mathrm{P}$ to soil affects plant uptake of As by competing for binding sites in the soil, thus enhancing solubility, and competing for transporters into the plants, thus reducing uptake of the soluble As (Woolson et al. 1973). However, there are no comparable studies on the possible effects of $\mathrm{P}$ on plant $\mathrm{Sb}$ uptake.

This study aimed to determine the extent of $\mathrm{Sb}$ translocation into the shoots of two crop plants, Zea mays (L.) and Helianthus annuus (L.) and to reveal whether phosphate addition affects plant uptake of $\mathrm{Sb}$. Our experiments used antimonate $\left(\mathrm{Sb}^{\mathrm{V}}\right)$, because it is the most common chemical species in water and soil solution (Filella et al. 2002). We chose a hydroponic system for our experiments to eliminate surface contamination and the influence of soil parameters.

\section{Material and methods}

We grew maize (Z. mays (L.) cv. Magister, a monocotyledon) and sunflower (H. annuus (L.) cv. Iregi, a dicotyledon) in a climate chamber (photoperiod $16 \mathrm{~h}$ ) with a temperature of $22^{\circ} \mathrm{C} / 14^{\circ} \mathrm{C}$ (day/ night) and light intensity of 11,000 lux. Seeds were germinated in quartz sand. After 2 weeks, they were transferred to $30-\mathrm{L}$ plastic boxes containing a modified Hoagland's nutrient solution. The nutrient solution consisted of $0.4 \mathrm{mM} \mathrm{Ca}\left(\mathrm{NO}_{3}\right)_{2}, 0.2 \mathrm{mM}$ $\mathrm{MgSO}_{4}, 0.1 \mathrm{mM} \mathrm{KH} \mathrm{PO}_{4}, 0.5 \mathrm{mM} \mathrm{KNO}{ }_{3}, 0.01 \mathrm{mM}$ $\mathrm{NaFe}$ (III)EDTA, $0.01 \mathrm{mM} \mathrm{H} \mathrm{BO}_{3}, 2 \mu \mathrm{M} \mathrm{MnSO}$, $0.2 \mu \mathrm{M} \mathrm{ZnSO}, 0.2 \mu \mathrm{M} \mathrm{CuSO}_{4}, 0.1 \mu \mathrm{M} \mathrm{Na} \mathrm{NoO}_{4}$, and $0.02 \mathrm{mM} \mathrm{NaCl}$ (Krämer et al. 1996).

Two weeks later, single plants were transferred to 1-L plastic vessels containing the treatment solutions. These comprised modified Hoagland's solution and added $\mathrm{Sb}$ in the absence or presence of phosphate $\left(\mathrm{PO}_{4}^{3-}\right)$ in the solution. Antimony was added as $\mathrm{KSb}(\mathrm{OH})_{6}$ to the nutrient solution at concentrations of $0,3,6,12,18$, and $24 \mathrm{mg} / \mathrm{L}$, in combination with either 0 or $3 \mathrm{mg} / \mathrm{L} \mathrm{P}$. Each treatment had two replicates. Solutions were adjusted to $\mathrm{pH} 6$ with $\mathrm{NaOH}$, continually aerated, and replaced weekly.

After 1 week in the treatment solutions, plants were harvested and the roots and shoots were separated and dried at $65^{\circ} \mathrm{C}$ to constant weight. Dried shoots were digested with aqua regia in closed Teflon vessels in microwave (MLS) digestion system. The 
total $\mathrm{Sb}$ concentrations were measured using hydride generation atomic fluorescence spectroscopy (HGAFS) (PSAnalytical). We analyzed a reference material (Virginia tobacco leaves IC-CTA-VTL2) and obtained a recovery of $94.5 \%$. Statistical analyses (analysis of variance and regression) were performed with SPSS 13.0 (SPSS 2004).

\section{Results}

Antimony produced no toxicity symptoms in the plants even at the highest Sb concentrations. There was no significant decrease in the biomass of plants treated with $\mathrm{Sb}$ compared to the untreated controls. The average dry biomass of the plants at the end of the experiment was $2.4 \pm 0.11 \mathrm{~g}$ for maize and $1.8 \pm 0.06 \mathrm{~g}$ for sunflowers. The water use during the 1 -week treatment was $0.22 \pm 0.01 \mathrm{~L}$ for maize and $0.22 \pm 0.006 \mathrm{~L}$ for sunflowers. In previously identical experiments using As, short-term phytotoxicity appeared at concentrations of $3 \mathrm{mg} / \mathrm{L}$ (Tschan and Schulin 2006). The experiments indicate that $\mathrm{Sb}$ is less phytotoxic than As. However, the 1-week length of our treatment period precludes any conclusions regarding $\mathrm{Sb}$ toxicity over the lifecycle of the plant.

Antimony uptake by both species was significantly and positively correlated with $\mathrm{Sb}$ concentration in the nutrient solution (Figs. 1 and 2). The maximum shoot Sb concentrations for $Z$. mays and $H$. annuus were 41 and $77 \mathrm{mg} / \mathrm{kg}$ dry wt., respectively. These occurred at respective solution concentrations of 18 and $30 \mathrm{mg} /$
L. There was no significant difference in Sb uptake between species. The average bioaccumulation coefficients, defined here as the plant/solution concentration quotients, were 0.93 and 1.33 for Z. mays and H. annuus, respectively, in absence of P. Phosphate addition had no significant effect on the uptake of $\mathrm{Sb}$ (Figs. 1 and 2). It neither increased growth nor induced phytotoxicity.

\section{Discussion}

Zea mays and $H$. annuus took up Sb from nutrient solution, and transported some into shoots. The extent of $\mathrm{Sb}$ translocation, as indicated by the bioaccumulation coefficient, was lower than that found for some other common trace elements. Tandy et al. (2006) found in similar experiments using $\mathrm{Cu}, \mathrm{Zn}$, and $\mathrm{Pb}$ that the bioaccumulation coefficients for sunflowers in hydroponics were: $6.2,123$, and 0.02 for $\mathrm{Cu}, \mathrm{Zn}$, and $\mathrm{Pb}$, respectively. Our experiments reveal the rate of $\mathrm{Sb}$ uptake over 1 week, rather than the total $\mathrm{Sb}$ accumulated over the lifetime of the plant. Therefore, the $\mathrm{Sb}$ concentration in mature plants may be different than we report here.

Johnson et al. (2005) found concentrations of up to $6 \mathrm{mg} / \mathrm{L} \mathrm{Sb}$ in leachates from shooting range soil samples with total $\mathrm{Sb}$ concentrations up to $10 \mathrm{~g} / \mathrm{kg}$. Based on this data and using our bioaccumulation coefficients, the predicted uptake, not allowing for any modifying soil factors, would be $5.6 \mathrm{mg} / \mathrm{kg}$ for maize and $8.0 \mathrm{mg} / \mathrm{kg}$ for sunflowers. Given that $100 \mathrm{mg} / \mathrm{d}$ is chronically toxic (Bowen 1979), an
Fig. 1 Antimony concentrations $(\mathrm{mg} / \mathrm{kg}$ dry matter) in the shoots of maize and the effect of adding of $3 \mathrm{mg} / \mathrm{L}$ phosphate to the ambient solutions

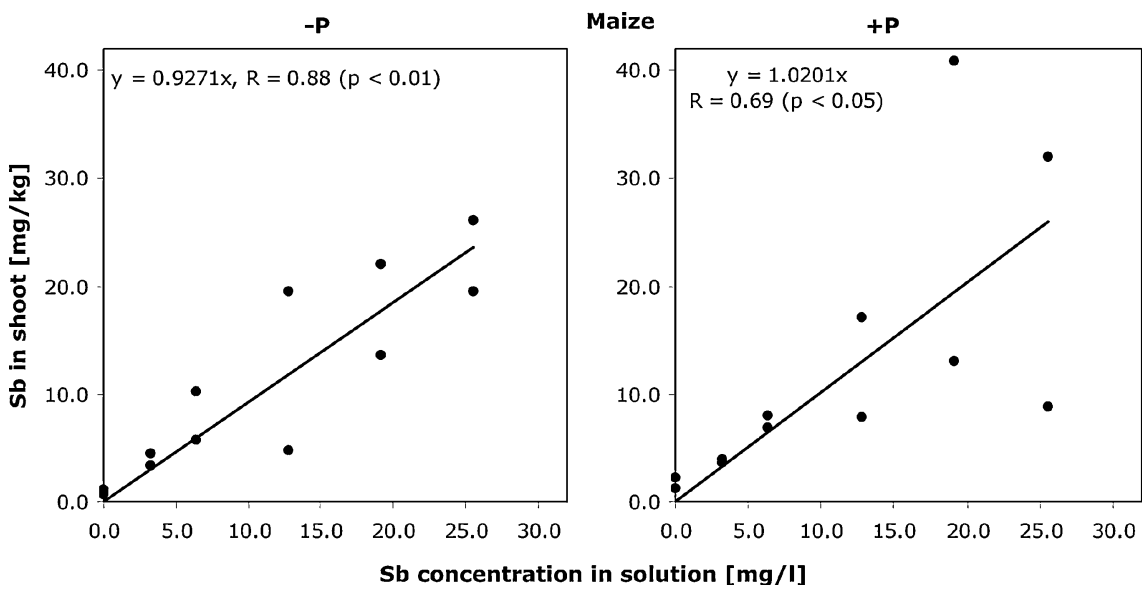


Fig. 2 Antimony concentrations $(\mathrm{mg} / \mathrm{kg}$ dry matter) in the shoots of sunflowers and the effect of adding of $3 \mathrm{mg} / \mathrm{L}$ phosphate to the ambient solutions

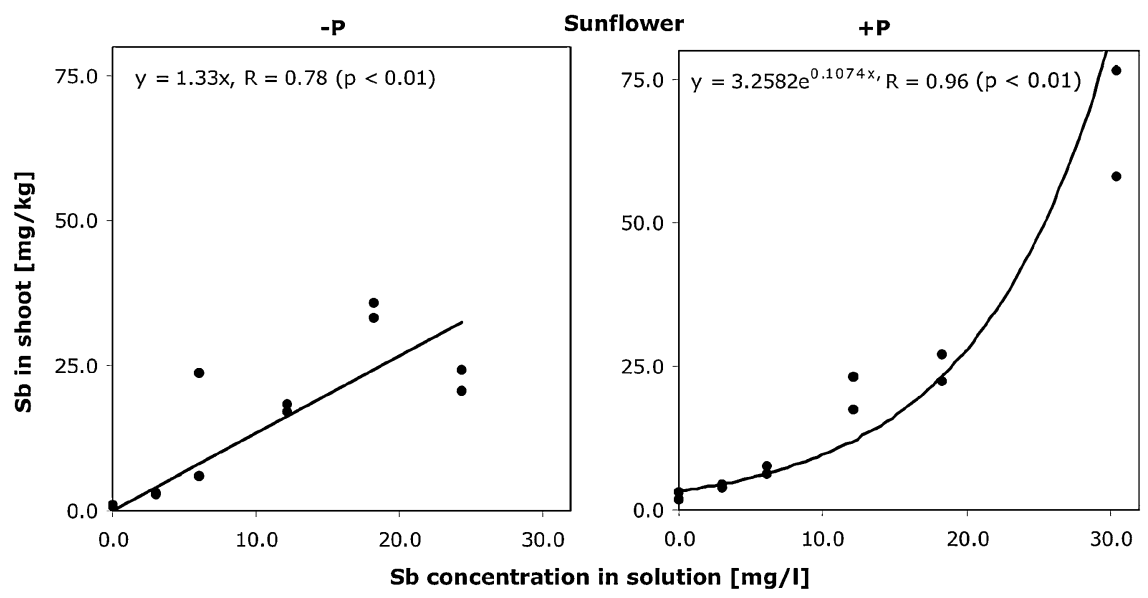

animal would have to consume more than $0.9 \mathrm{~kg}$ of maize or $1.3 \mathrm{~kg}$ of sunflower a day (assuming concentrations of $77 \mathrm{mg} / \mathrm{kg}$ in sunflowers) over a longer period. The direct consumption of soil (which contained up to $10,000 \mathrm{mg} / \mathrm{kg} \mathrm{Sb}$ ) by herbivores or children poses a greater threat.

The observation that phosphate did not affect the uptake and toxicity of $\mathrm{Sb}$ indicates that $\mathrm{Sb}$, unlike As, is not taken up via the phosphate pathway. This may be due to the different structures of their pentavalent oxyanions. Arsenate $\left(\mathrm{AsO}_{4}^{3-}\right)$ is tetrahedral while $\mathrm{Sb}(\mathrm{OH})_{6}^{-}$is octahedral (Baes and Mesmer 1986). The linear uptake of $\mathrm{Sb}$ by plants in these experiments indicates that plants either taken up $\mathrm{Sb}$ by another selective pathway, which was not at saturation in our experiment, or via a nonselective apoplastic pathway (Bell et al. 2003).

Acknowledgements We gratefully acknowledge A. Grünwald, R. Saladin, and Viktor Stadelmann for their continuous help and support in the laboratory. This project was financially supported by the Swiss National Science Foundation (Grants No. 200021-103768).

\section{References}

Ainsworth, N., Cooke, J. A., \& Johnson, M. S. (1990a). Distribution of antimony in contaminated grassland. 1. Vegetation and soils. Environmental Pollution, 65, 6577.

Ainsworth, N., Cooke, J. A., \& Johnson, M. S. (1990b). Distribution of antimony in contaminated grassland. 2. Small mammals and invertebrates. Environmental Pollution, 65, 79-87.
Baes C. F., \& Mesmer, R. E. (1986). Arsenic, antimony, bismuth. The hydrolysis of cations (pp. 366-375). Malabar, Fl: Krieger.

Baroni, F., Boscagli, A., Protano, G., \& Riccobono, F. (2000). Antimony accumulation in Achillea ageratum, Plantago lanceolata and Silene vulgaris growing in an old Sbmining area. Environmental Pollution, 109, 347-352.

Bell, P. F., McLaughlin, M. J., Cozens, G., Stevens, D. P., Owens, G., \& South, H. (2003). Plant uptake of C-14EDTA, C-14-citrate, and C-14-histidine from chelatorbuffered and conventional hydroponic solutions. Plant and Soil, 253, 311-319.

Bowen, H. J. M. (1979). Environmental chemistry of the elements. London: Academic Press.

EU (2005). Commission directive 2005/79/EC.

Filella, M., Belzile, N., \& Chen, Y. W. (2002). Antimony in the environment: A review focused on natural waters. I. Occurence. Earth-Science Reviews, 57, 125-176.

Gresch, M., \& Wettstein, B. (2002). Antimon- und Bleibelastung bei Schiessanlagen. Fallbeispiel Eschenbach (SG), Semesterarbeit. Zurich, ETH.

Johnson, C. A., Moench, H., Wersin, P., Kugler, P., \& Wenger, C. (2005). Solubility of antimony and other elements in samples taken from shooting ranges. Journal of Environmental Quality, 34, 248-254.

Krachler, M., Emons, H., \& Zheng, J. (2001). Speciation of antimony for the 21 st century: Promises and pitfalls. TracTrends in Analytical Chemistry, 20, 79-90.

Krämer, U., Cotter-Howells, J. D., Charnock, J. M., Baker, A. J. M., \& Smith, J. A. C. (1996). Free histidine as a metal chelator in plants that accumulate nickel. Nature, 379, 635-638.

Pratas, J., Prasad, M. N. V., Freitas, H., \& Conde, L. (2005). Plants growing in abandoned mines of Portugal are useful for biogeochemical exploration of arsenic, antimony, tungsten and mine reclamation. Journal of Geochemical Exploration, 85, 99-107.

Rish, M. A. (2004). Antimony. In: E. Merian, M. Anke, M. Ihnat, \& M. Stoeppler (Eds.), Elements and their compounds in the environment (2nd ed., Vol. 2, pp. 659-670). Weinheim: Wiley-VHC. 
Rooney, C. P., McLaren, R. G., \& Cresswell, R. J. (1999). Distribution and phytoavailability of lead in a soil contaminated with lead shot. Water Air Soil Pollution, 116, 535-548.

Swartjes, F. A. (1999). Risk-based assessment of soil and groundwater quality in the Netherlands: Standards and remediation urgency. Risk Analysis, 19, 1235-1249.

Tandy, S., Schulin, R., \& Nowack, B. (2006). The influence of EDDS on the uptake of heavy metals in hydroponically grown sunflowers. Chemosphere, 62, 1454-1463.

Tschan, M., \& Schulin, R. (2006). Poster: Phytoavailability and plant uptake of antimony, workshop: Bioavailability of pollutants and soil remediation 2006, Sevilla, Spain, Programme and Abstracts, p. 118.

Wersin, P., Johnson, C. A., \& Furrer, G. (2002). Antimony contamination in soil and ground water by shooting range activities. Geochimica et Cosmochimica Acta, 66, A829A829.

Woolson, E. A., Axley, J. H., \& Kearney, P. C. (1973). Chemistry and phytotoxicity of arsenic in soils. 2. Effects of time and phosphorus. Soil Science Society of America Journal, 37, 254-259. 